\title{
APLIKASI SITOGENETIKA UNTUK MENDETEKSI ABNORMALITAS KROMOSOM PADA Benign Barrett's EPITHELIUM YANG MENGALAMI TRANSFORMASI MALIGNA
}

\author{
Alvi Milliana \\ Jurusan Biologi, Fakultas Sains dan Teknologi UIN Maliki Malang \\ Email: alvimilliana@yahoo.com
}

\begin{abstract}
Barrett's esophagus is a metaplastic alteration of the normal distal esophageal epithelium. Barrett's esophagus is present in 10\%-20\% of patients with gastroesophageal reflux disease (GERD). Its major significance is as a predisposing factor for esophageal adenocarcinoma, which carries a high mortality rate and a rapidly growing incidence in the United States. Esophageal adenocarcinoma carries a grave prognosis, with a relative 3-year survival rate of only 20\% in the United States from 1995-1998. Cancer arises in BE through a multistep sequence of events initiated by chronic GERD that leads to metaplasia, dysplasia, and adenocarcinoma sequence. Primary pathogenetic changes in cancer result from balanced rearrangements of chromosome. Losses of chromosomes 4, 18, 21, and $Y$ were the most frequent numeric changes. The chromosome arms most frequently rearranged were $1 p, 3 q, 11 p$ and $22 p$. Evidence of chromosomal rearrangements [t(10;16) and dup (11q)] appeared during the early stages of the BEC model. After further validation, in-vivo, they may be clinically useful for diagnosis of BE, progressing to dysplasia or esophageal adenocarcinoma.
\end{abstract}

Keywords: Barrett's esophagus, esophageal adenocarcinoma, chromosome instability, cytogenetics

\section{Pendahuluan}

Barrett's Esophagus (BE) merupakan gangguan metaplastik intestinal dari epitel esophagus bagian distal, terjadi akibat dari komplikasi Gastroesofageal Reflux Disease (GERD) dan merupakan kondisi terbanyak yang mendahului keganasan Esopagheal Adenokarsinoma (EAC) (Jenses et al., 2011). EAC memiliki prognosis yang buruk, dengan angka harapan hidup 3 tahun di Amerika adalah 20\% dari tahun 1995-1998 (Modiano and Gerson, 2007). Di Eropa dan Amerika, insiden EAC meningkat 6 kali lipat pada 25 tahun terakhir ini (Oryu, et al, 2013). Trend prevalensi GERD di Asia meningkat. Di Hongkong meningkat dari $29,8 \%$ (2002) menjadi 35\% (2003). Sedangkan berdasarkan data salah satu rumah sakit di Indonesia, RSCM menunjukkan peningkatan signifikan dari $6 \%$ menjadi $26 \%$ dalam kurun waktu 5 tahun (Renoat, 2013). BE lebih banyak dijumpai pada laki-laki (10:1). GERD dapat terjadi di segala usia, namun prevalensinya meningkat pada usia diatas 40 tahun (Ndraha, 2014)
Penyebab pasti dari BE belum diketahui, tetapi GERD merupakan faktor resiko terbesar. BE telah nampak beberapa tahun sebelum berkembang menjadi kanker. Biasanya sebelum kanker tampak, sel prekanker telah ditemukan pada jaringan Barrett's, yaitu displasia, dan hanya terlihat dengan biopsi (NIDDK, 2008).

Pada tahun 1960, Peter Nowell dan David Hungerford menemukan untuk pertama kalinya adanya hubungan abnormalitas kromosom dengan kanker menggunakan sitogenetik. Abnormalitas kromosom ini merupakan tanda deregulasi gen pada kanker dan menyebabkan adanya instabilitas genom. Para peneliti membuat sebuah hipotesis bahwa patogenesa kanker merupakan hasil dari rearrangement chromosome. Kanker adalah suatu keadaan yang bertahap, progresif, dan menyebabkan perubahan pada kromosom. Abnormalitas kromosom ini menyebabkan perubahan proliferasi sel (Lobo, 2008).

Barrett's Esophagus Carcinogenesis 
Barrett's esophagus (BE) adalah kondisi dimana epitel squamous esophagus digantikan oleh epitel kolumnar metaplastik yang terdiri dari sel kolumnar dan sel goblet (McPhee and Papadakis, 2007). Faktor etiologi utama terjadinya BE adalah gastroesofageal refluks disease (GERD) yang kronis. GERD mempunyai dua komponen utama yang bekerja sinergi menginduksi terjadinya luka pada epitel mukosa, yaitu asam dan empedu (Das et al., 2011). Hal ini menyebabkan terjadinya perbaikan epitel, berupa penggantian epitel squamous dengan epitel kolumner. Epitel kolumner lebih tahan terhadap $\mathrm{pH}$ rendah tetapi juga merupakan tendensi terhadap perubahan dysplasia yang merupakan predisposisi esophageal adenocarsinoma (EAC). Pergantian epitel normal pada esophagus bagian distal dengan epitel kolumnar disebut dengan proses metaplastik, yang ditandai dengan adanya histologi kolumnar pada jaringan yang terganggu, dan disebut sebagai metaplasia intestinal special yang terdiri dari kripta intestine dan sel goblet (Modiano and Gerson, 2007). Perubahan keganasan pada BE merupakan perubahan morfologi yang berurutan dari metaplasia menjadi dysplasia, lalu menjadi carcinoma (Das et al., 2011).

Paparan sel terhadap bahan-bahan genotoksik dan sitotoksik memiliki potensi untuk menimbulkan perubahan pada stabilitas genom seluler. Beberapa perubahan ini menginduksi kerusakan DNA baik secara langsung maupun tidak langsung, sehingga menyebabkan peningkatan mutasi gen, amplifikasi dan abnormalitas karyotype multiple. Kerusakan DNA ini merupakan faktor penting yang berperan pada manifestasi instabilitas kromosom (Limoli, 2003).

Perkembangan progresifitas keganasan diduga merupakan akibat dari instabilitas kromosom yang didapat dan evolusi pada populasi klonal dengan akumulasi kesalahan genetik. Kanker pada manusia dan beberapa lesi premaligna memiliki abnormalitas genetik yang multiple. BE adalah kondisi premaligna yang merupakan predisposisi EAC. Untuk deteksi dini kanker EAC diperlukan biopsi melalui endoskopi (Barrett's, 1999).

Progresi neoplastik pada BE berhubungan dengan gangguan TP53 (p53) dan CDKN2A (p16) (Barrett's, 1999). Sebuah penelitian telah menganalisa peran abnormalitas genetik berupa allelic loss dan mutasi pada gen p16 dan p53 pada progresi BE menjadi EAC.
Sel epitel normal memiliki dua kopi p53. Pada pasien yang mengalami displasia epitel kedua kopi p53 diinaktifkan melalui allelic loss dan mutasi. Gangguan gen p53, baik berupa loss of heterozygosity $(\mathrm{LOH})$ atau mutasi pada exon 58 , sering terjadi pada kanker manusia. Terjadinya LOH pada gen ini sebesar $92 \%$ pada adenokarsinoma dan $27 \%$ pada low grade dysplasia. Tumor supressor gene yang lain, p16/CDKN2/MTS 1, sering terlibat pada perkembangan kanker manusia. Gen ini terletak pada kromosom 9p21, daerah yang sering mengalami delesi pada beberapa tipe kanker, termasuk EAC. CDKN2 adalah protein yang membentuk kompleks dengan Cdk 4 dan Cdk6, sehingga menghambat fosforilasi protein retinoblastoma (pRB). pRB yang tidak terfosforilasi mencegah sel melanjutkan siklus sel. Jadi, hilangnya gen p16 menyebabkan sel terus tumbuh dan membelah. Hal ini merupakan sebuah karakteristik dari kanker. Hilangnya fungsi p16 terjadi melalui 3 mekanisme mayor, yaitu mutasi nukleotida, delesi gen dan hilangnya ekspresi setelah metilasi pada $C p G$ island yang terletak pada ujung 5' (Gonzales et al., 1997).

Gangguan jumlah kromosom, baik penambahan maupun pengurangan, terjadi melalui beberapa mekanisme, termasuk mitosis non-disjuction, kelainan spindle checkpoint atau gangguan polaritas pembelahan sel. Pada kanker, sering dijumpai kelainan jumlah sentrosom yang dapat menyebabkan pembentukan spindle mitosis multipolar yang meningkatkan pembelahan sel asimetri sehingga meningkatan resiko penambahan atau pengurangan jumlah kromosom. Beberapa protein kinase, termasuk cyclin E/CDK2 dan cyclin $\mathrm{A} / \mathrm{CDK} 2$ yang menentukan progresi siklus sel juga ikut meregulasi duplikasi sentrosom pada sel mamalia pada saat transisi G1/S. Duplikasi sentrosom diikuti oleh duplikasi sentriol sehingga menyebabkan kelainan mitosis terkait sentrosom (Duensing, 2003).

Pada BE juga terjadi abnormalitas pada kromosom 7 yaitu berupa trisomi 7 . Kromosom 7 memiliki protoonkogen c-erb-B yang mengkode epidermal growth factor receptor (EGFR). Trisomy kromosom 7 pada BE menyebabkan overekspresi EGFR. Overekspresi EGFR dapat ditemukan pada kondisi pre-maligna (Garewall, 1990). Populasi sel 4N (tetraploid) merupakan predisposisi perkembangan aneuplodi selama progresi 
neoplastik. Inaktivasi p53 berhubungan dengan perkembangan aneuploidi dan instabilitas genetik. Adanya spindle checkpoint pada siklus sel dapat mencegah instabilitas genetik akibat paparan bahan genotoksik dengan cara menghentikan siklus sel (Galipeau et al., 1996).

\section{Sitogenetika pada Barret's Esophagus}

Dua peneliti utama yang melakukan studi model dinamis BE carcinogenesis (BEC) in-vitro adalah Das et al (2011) serta Bajpai et al (2012). Keduanya melakukan studi pada model dinamis BEC in-vitro yang dikembangkan dari naïve sel BAR-T jinak yang mendapat paparan asam ( $\mathrm{pH} 4)$ dan empedu glycochenodeoxycolic acid (GCDA) selama 5 menit setiap hari selama sekitar satu tahun. Sel BAR-T merupakan hTERT immortal dari Barrett's epithelium cell line. Bajpai et al memberikan paparan asam dan empedu, glycochenodeoxycholic acid pada pH 4 (B4), selama 5 menit setiap hari pada sel BAR-T. Perlakuan ini dilakukan selama lebih dari 65 minggu untuk membuat model BEC. Sel tanpa perlakuan ditumbuhkan paralel sebagai kontrol . Setiap 8-10 minggu sel dari grup kontrol dan perlakuan dilakukan karyotyping. Analisis sitogenetik dilakukan pada berbagai titik waktu, dimulai dengan sel BAR-T naïve atau yang belum mendapat perlakuan sampai dengan 78 minggu perlakuan. Analisis sitogenetik juga dilakukan pada kontrol dan 9 koloni yang dikembangkan pada soft agar yang diambil dari sel BAR-T yang dipapar B4 selama 78 minggu. Karyotyping dilakukan dengan menggunaan pewarnaan Trypsin G-binding yang merupakan modifikasi dari metode Seabright's. Hasil karyotipe pada perlakuan 18 minggu didapatkan 5 variasi klonal berdasarkan perbedaan karyotipe (Gambar 1).

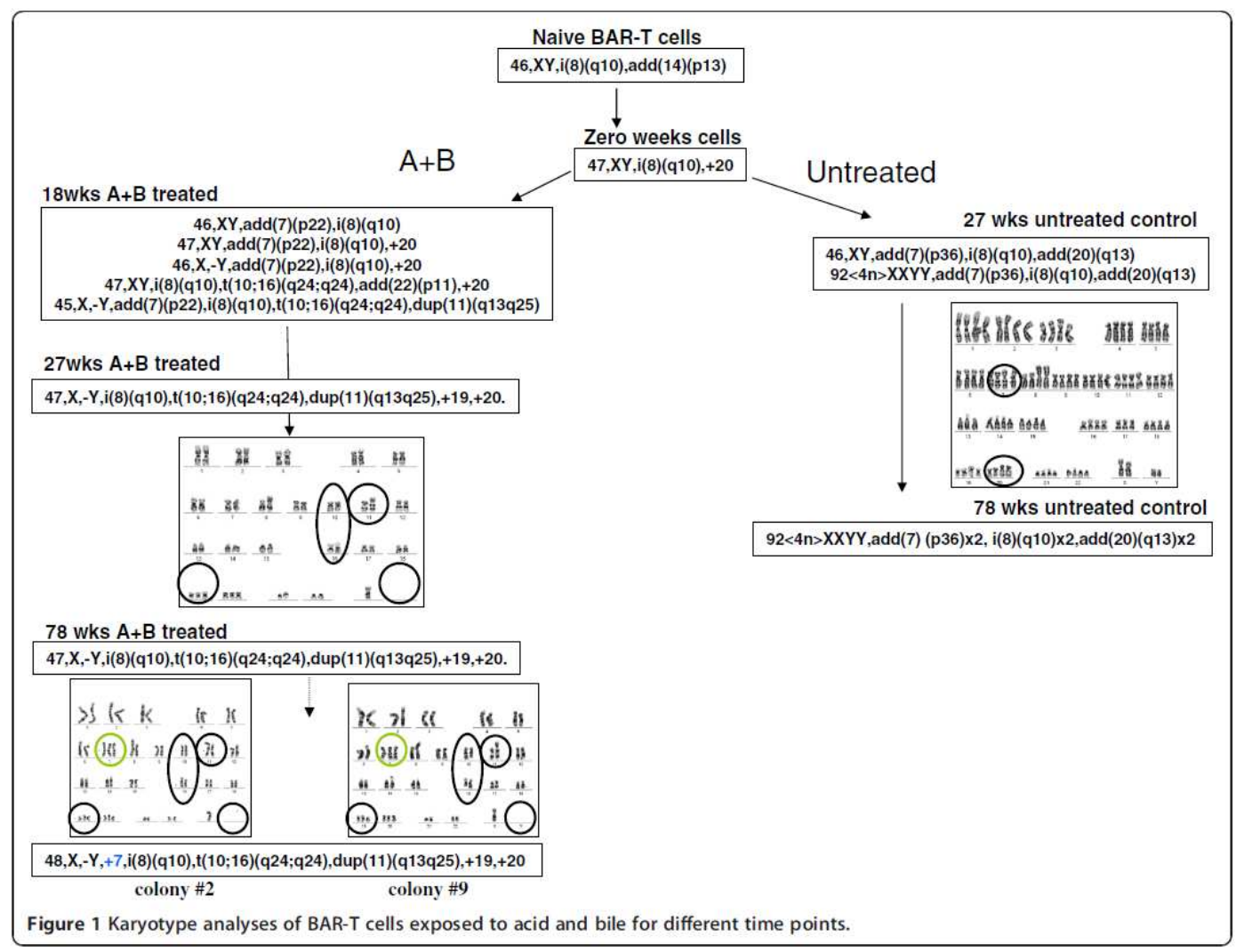

Gambar 1. Analisis karyotype sel BAR-T yang dipapar asam dan empedu pada berbagai ttik waktu yang berbeda (Bajpai et al., 2012)

Hasil perubahan profil sitogenetika sel line BAR-T dari gambar 1 diperjelas pada tabel 1. Sel BAR-T pada model BEC mempunyai abnormalitas kromosom, yaitu hilangnya kromosom Y, translokasi diantara lengan panjang kromosom 10 dan 16 [t(10;16)(q24;q24)], duplikasi lengan panjang kromosom 11, dup(11) (q13q25) dan trisomy 19 dan 20 tetapi mempertahankan 
isokromosom 8q. Sel kontrol tidak menunjukkan abnormalitas ini. Perubahan kromosom yang diobservasi pada sel BEC merupakan akibat dari paparan asam dan empedu jangka lama yang menyebabkan kerusakan DNA (Bajpai et al., 2012).

Tabel 1. Perubahan profil sitogenetik cell line BAR-T akibat paparan asam dan empedu ( $\mathrm{pH} 4)$ kronis intermiten (Bajpai et al., 2012)

\begin{tabular}{lcccccccc}
\hline & Chr \# & $(-Y)$ & add $(7 p)$ & $\mathbf{i}(8)(q 10)$ & $\mathbf{t}(10 ; 16)$ & dup(11q) & $(+19)$ & $(+20)$ \\
\hline BAR-T A+B 18 wks & 46,47 & $(+) 2 / 14$ & $(+) 12 / 14$ & $(+)$ & $(+) 2 / 14$ & $(+) 1 / 14$ & & $(+) 7 / 14$ \\
BAR-T A+B 27 wks & 47 & $(+)$ & & $(+)$ & $(+)$ & $(+)$ & $(+)$ & $(+)$ \\
BAR-T A+B 48 wks & 47 & $(+)$ & & $(+)$ & $(+)$ & $(+)$ & $(+)$ & $(+)$ \\
BAR-T A+B 65 wks & 47 & $(+)$ & & $(+)$ & $(+)$ & $(+)$ & $(+)$ & $(+)$ \\
BAR-T A+B 78 wks & 47 & $(+)$ & & $(+)$ & $(+)$ & $(+)$ & $(+)$ & $(+)$ \\
\hline
\end{tabular}

Bajpai et al. juga melakukan analisa sitogenetik pada 9 koloni sel BAR-T. Sekitar $11 \%$ dari sel BAR-T yang dipapar dengan B4 selama 78 minggu membentuk koloni pada soft agar (110 dari 1000 sel pada plate). Hasilnya menunjukkan bahwa masing-masing koloni yang tumbuh pada soft agar tersebut merepresentasikan transformasi klon yang independen. Karena masing-masing koloni tidak menggambarkan kesamaan kariotipe dengan sel induk B4 78 minggu (gambar 4). Koloni ini memiliki karyotipe: 48, X,-Y, +7, i(8)(q10), t(10;16)(q24;q24), dup(11)(q13q25), +19, +20. Dapat dilihat adanya karakteristik tambahan berupa trisomi 7 yang tidak ditemukan pada sel induk B4 78 minggu. Sehingga trisomi 7 diduga berperan penting dalam pembentukan koloni pada soft agar (Bajpai et al., 2011).

Tabel 2. Profil sitogenetik koloni yang diturunkan dari sel BAR-T yang mendapat paparan $A+B$ selama 78 minggu (Bajpai et al., 2012)

\begin{tabular}{lcllccccc}
\hline & Chr \# & $(-\mathbf{Y}$ & $(+7)$ & $\mathbf{i}(\mathbf{8})(\mathbf{q} 10)$ & $\mathbf{t}(10 ; 16)$ & dup(11q) & $(+19)$ & $(+20)$ \\
\hline BAR-T A+B 78 wks & 47 & $(+)$ & & $(+)$ & $(+)$ & $(+)$ & $(+)$ & $(+)$ \\
Colony 1 cell line & 48 & $(+)$ & $(+)$ & $(+)$ & $(+)$ & $(+)$ & $(+)$ & $(+)$ \\
Colony 2 cell line & 48 & $(+)$ & $(+)$ & $(+)$ & $(+)$ & $(+)$ & $(+)$ & $(+)$ \\
Colony 3 cell line & 48 & $(+)$ & $(+)$ & $(+)$ & $(+)$ & $(+)$ & $(+)$ & $(+)$ \\
Colony 4 cell line & 48 & $(+)$ & $(+)$ & $(+)$ & $(+)$ & $(+)$ & $(+)$ & $(+)$ \\
Colony 5 cell line & 48 & $(+)$ & $(+)$ & $(+)$ & $(+)$ & $(+)$ & $(+)$ & $(+)$ \\
Colony 6 cell line & 48 & $(+)$ & $(+)$ & $(+)$ & $(+)$ & $(+)$ & $(+)$ & $(+)$ \\
Colony 7 cell line & 48 & $(+)$ & $(+)$ & $(+)$ & $(+)$ & $(+)$ & $(+)$ & $(+)$ \\
Colony 8 cell line & 48 & $(+)$ & $(+)$ & $(+)$ & $(+)$ & $(+)$ & $(+)$ & $(+)$ \\
Colony 9 cell line & 48 & $(+)$ & $(+)$ & $(+)$ & $(+)$ & $(+)$ & $(+)$ & $(+)$ \\
\hline
\end{tabular}

Analisis sitogenetik yang dilakukan oleh Bajpai et al. pada sel kontrol, didapatkan hasil adanya kesamaan kariotipe dengan sel naïve (tabel 3). Pada kontrol 76 minggu sel BAR-T mempertahankan kromosom Y, tetapi pada model BEC terjadi kehilangan kromosom Y pada awal 18 minggu. Penambahan segmen kromosom add (7p) dan add (20q) dan perkembangan poliploidi pada kontrol tidak merubah bentuk sel karena sel tidak mampu membentuk koloni pada soft agar dan dianggap sebagai sel non-neoplastik (Bajpai et al., 2012).

Tabel 3. Profil sitogenetik pada sel BAR-T kontrol selama kultur jangka panjang (Bajpai et al., 2012)

\begin{tabular}{|c|c|c|c|c|c|c|c|c|c|}
\hline & Chr\# & $-Y$ & $\operatorname{add}(7 p)$ & $\mathrm{i}(8)(q 10)$ & $t(10 ; 16)$ & dup(11q) & +19 & +20 & $\operatorname{add}(20 q)$ \\
\hline BAR-T 0 wks & 46 & & & + & & & & & \\
\hline \multirow[t]{2}{*}{ BAR-T 27 wks } & 46 & & + & + & & & & & + \\
\hline & 92 & & + & + & & & & & + \\
\hline BAR-T 76 wks & 91 & & + & + & & & & & + \\
\hline
\end{tabular}


Bajpai et al. kemudian melakukan analisis STR (small tandem repeat) pada sel naïve dan sel BAR-T 78 minggu untuk menghilangkan kontaminasi cell line selama kultur jangka panjang. STR dilakukan dengan menggunakan 10 marker untuk menganalisa kedua grup sel. Cell line BAR-T diturunkan dari pasien laki-laki yang memiliki kromosom $\mathrm{X}$ dan Y seperti pada sel naïve dan kontrol. Amelogenin Y tidak terdeteksi pada sel BART 78 minggu. Hal ini menunjukkan bahwa telah terjadi kehilangan kromosom Y selama transformasi sel (tabel 4) (Bajpai et al., 2012). Tabel 4. Profil STR pada cell line BAR-T (Bajpai et al., 2012)

\begin{tabular}{lll}
\hline Markers & $\mathbf{7 8 w k s ( A + B )}$ & naive BAR-T \\
\hline D5S818 & 16 & 16 \\
D21S11 & 24 & 24 \\
D16S539 & 9,12 & 9,12 \\
D5S818 & 7 & 7 \\
CSF1PO & 14 & 14 \\
DBS1179 & 13 & 13 \\
D5S818 & 16 & 16 \\
D21S11 & 24 & 24 \\
FGA & 21,24 & 21,24 \\
AMELOGENIN & $X$ & $X, Y$ \\
\hline
\end{tabular}

Das et al. melakukan penumbuhan koloni dari sel BAR-T yang telah dipapar Hydrochloric acid dan glycochenodeoxycholic acid selama 5 menit setiap hari pada special supplemented keratinocyte medium 2. Dari penelitian sebelumnya dikatakan bahwa waktu 5 menit cukup untuk menginduksi jalur sinyal tranduksi sebagai regulasi sel tanpa merusak sel. Sel BAR-T pada 78 minggu paparan B4 ditumbuhkan pada soft agar untuk dilihat pertumbuhan koloninya. Dilakukan penumbuhan koloni sebanyak 9 koloni independen pada soft agar yang diambil dari 78 minggu paparan B4 pada sel BAR-T. Pertumbuhan koloni sel BAR-T mulai tampak pada minggu ke 58. Jumlah koloni, baik pada koloni kecil $(<1 \mathrm{~mm})$ maupun besar $(>1 \mathrm{~mm})$, secara progresif meningkat sejalan dengan makin lamanya paparan dengan asam dan empedu (gambar 2) Sekitar $11 \%$ dari sel BAR$\mathrm{T}$ yang dipapar dengan $\mathrm{B} 4$ selama 78 minggu membentuk koloni pada soft agar (110 dari 1000 sel pada plate) (Das et al., 2011).

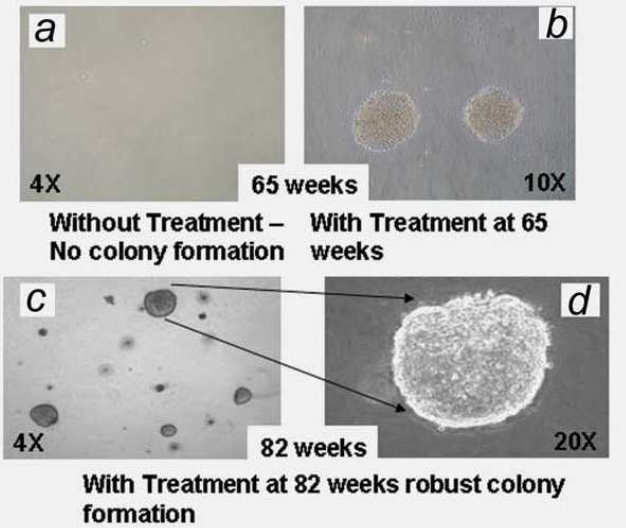

Gambar 2. Pembentukan koloni sel BAR-T pada soft agar akibat paparan B4 selama 65 minggu

(Das et al., 2011)

Das el al. melakukan injeksi sel BAR$\mathrm{T} 10^{7}$ yang telah diberi perlakuan dengan Hydrochloric acid dan glycochenodeoxycholic acid. Hasilnya menunjukkan adanya pertumbuhan tumor pada tikus setelah diinjeksi selama 3 minggu. Sebagai kontrol adalah tikus yang mendapatkan injeksi sel BAR-T tanpa perlakuan (gambar 3).



Treated BAR-T cells

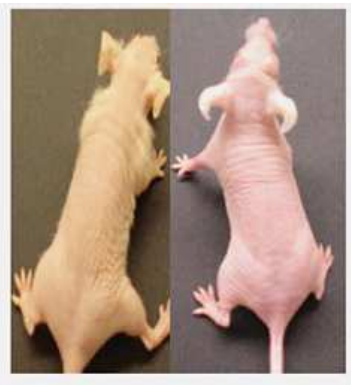

Untreated BAR-T cells
Gambar 3. Injeksi sel BAR-T yang telah dipapar dengan Hydrochloric acid dan glycochenodeoxycholic acid selama 67 minggu dapat menumbuhkan tumor pada tikus setelah mendapat injeksi selama 3 minggu

Laboratorium

NeoGenomics menggunakan FISH (Fluoresence in situ Hybridization), salah satu bentuk sitogenetika yang menggunakan teknik fluoresen, untuk mengidentifikasi pasien $\mathrm{BE}$ yang memiliki resiko tinggi menjadi EAC. FISH memiliki 4 penanda (probe) terhadap adanya penambahan maupun kehilangan MYC (8q24), p16 (CDKN2A at 9p21), HER2 (ERBB2 at 17q12), dan ZNF217 (20q13) yang merupakan penanda $\mathrm{BE}$ dengan resiko tinggi menjadi EAC. NeOSITE BE merupakan pemeriksaan 
FISH menggunakan sampel yang berasal dari bilasan sitologi Barrett's esophagus untuk membedakan kasus dengan resiko tinggi kanker dengan resiko rendah. FISH juga memiliki keunggulan dibanding biopsi dalam hal teknik pengumpulan sampel, dimana FISH dapat dilakukan dengan cepat dan menjangkau area pemeriksaan yang luas karena pengumpulan sampel FISH dilakukan dengan menggunakan bilasan esofagus. Pemeriksaan ini dapat membandingkan adanya kelebihan ataupun kehilangan kromosom dari sampel pasien yang diduga mengalami EAC atau
NORMAL

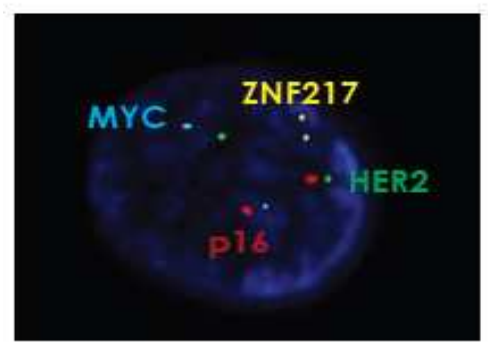

A normal esophageal cell nucleus with the expected two signals from each probe. high-grade displasia dengan low-grade dysplasia dan non-dysplasia. Tes ini juga dapat menentukan prognosis BE. NeoSITE B.E. mampu mengidentifikasi abnormalitas genetik pada pasien dengan BE sehingga dapat ditentukan penanganan tambahan selanjutnya maupun terapi yang akan diberikan.Tes ini memiliki sensitivitas $86 \%$ dan spesifitas $67 \%$ untuk membedakan kelompok dengan resiko tinggi dan resiko rendah (NeoGenomic Laboratory, 2013).

\section{ABNORMAL}

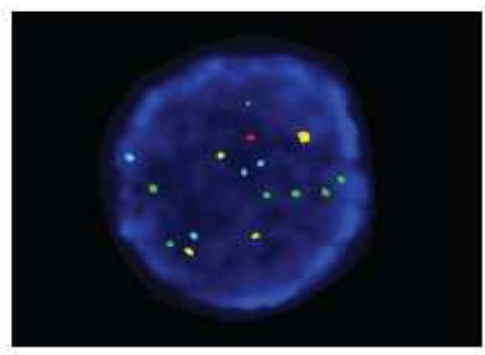

An abnormal esophageai cell nucleus with one pl6 signal missing and extra signals from all other probes.

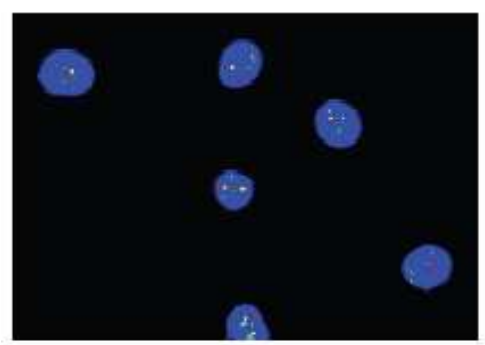

Normal FISH results in nuclei of an esophageal cytology brushing.

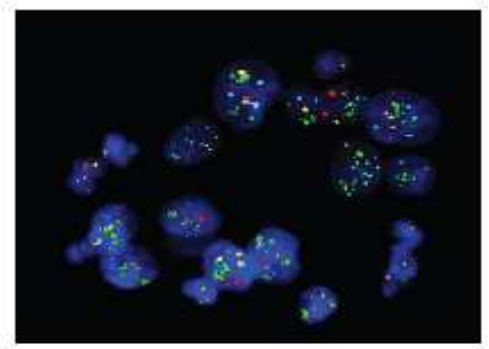

Esophageal brushings with majority of nuclei demonstrating FISH abnormalities.

Gambar 4. Perbedaaan sel esofagus normal dan abnormal dengan menggunakan FISH (NeoGenomic Laboratory, 2013).

Berbagai penelitian pada dekade terakhir telah membuktikan hubungan antara keempat marker yang dijadikan sebagai probe dengan progresifitas BE. Kemampuan keempat probe untuk membedakan berbagai derajat BE pertama kali diperkenalkan oleh Brankley pada tahun 2006 (NeoGenomic Laboratory, 2013).

\section{Analisis Hasil Sitogenetika pada Barret's Esophagus}

Penelitian sitogenetik yang dilakukan oleh Menke Pluymers et al. pada tahun 1996 terhadap 37 kasus adenokarsinoma esophagus, menunjukkan bahwa terdapat abnormalitas karyotipe, yaitu 11 kasus menunjukkan perubahan yang kompleks dan multiple; 8 kasus menunjukan satu atau sedikit perubahan. Perubahan jumlah kromosom yang paling sering terjadi adalah akibat kehilangan kromosom 4,18, 21, dan Y. Sedangkan perubahan struktur nampak pada 13 kasus. Perubahan struktur paling sering terjadi pada lengan 1p, 3q, 11q dan 22p. Kehilangan lengan kromosom paling sering terjadi pada $1 \mathrm{p}$, sedangkan lengan kromosom yang sering 
mengalami penambahan adalah $11 \mathrm{p}, 22 \mathrm{p}$ dan i(3q) (Pluymers et al., 1996).

Paparan kronis sel terhadap stres oksidatif meningkatkan instabilitas genomik yang ditandai dengan perubahan jumlah atau struktur kromosom. Beberapa hipotesis mendukung peranan abnormalitas kromosom terhadap progresi keganasan. Kombinasi instabilitas genetik dan ekpansi klonal mempunyai peran terhadap progresifitas $\mathrm{BE}$ menjadi EAC. Model BEC menunjukkan adanya instabilitas genomik dan seleksi/ekspansi klonal selama evolusi karyotipe. Hal ini merupakan perbedaan karakteristik dari sel BAR-T kontrol. Model BEC juga menunjukkan perubahan morfologi dan neoplastik (Bajpai et al., 2012; Das et al., 2011).

Kebanyakan sel tumor menunjukkan perubahan atau evolusi karyotype selama kultur jangka panjang. Tahap awal establishment pada cell line ditandai dengan heterogenitas karyotipik akibat instabilitas genomik. Klon yang beradaptasi untuk tumbuh pada kondisi paparan terseleksi sebagai sel line yang mencapai tahap stabilisasi dengan heterogenitas karyotype minimal (Bajpai et al., 2012; Das et al., 2011). Kebanyakan spesimen sel yang diambil dari biopsi pasien BE menunjukkan hilangnya kromosom Y. Abnormalitas kromosom dan fenotip ini dianggap sebagai karakteristik patogenesis $\mathrm{BE}$ berupa sekuen metaplasia-displasia-karsinoma (Bajpai et al., 2012; Schneider and Martin, 2004).

Pada biopsi Barrett's epithelium tampak trisomi 7 dengan disertai peningkatan ekspresi gen epidermal growth factor receptor (EGFR) yang berlokasi pada kromosom 7. Peningkatan EGFR menyebabkan peningkatan ikatan EGF. Peningkatan EGFR mungkin berkaitan dengan peningkatan pertumbuhan tumor jaringan padat. Trisomi 7 yang didapatkan pada cell line dari koloni soft agar memperburuk potensi tumorigenik. Hanya $11 \%$ pada 78 minggu sel model BEC yang menunjukkan abnormalitas ini (Garewall, 1990).

Pengulangan atau amplifikasi kromosom regio $11 \mathrm{q} 13$ sering ditemukan pada keganasan payudara dan daerah kepala-leher. Pada keganasan ini, amplifikasi daerah 11q13 memiliki marker prognostic yang dapat mengidentifikasi subgroup pasien dengan resiko tinggi keganasan. Gen yang terdapat pada kromosom 11, INT2-FGFR3, HSR1FGF4 dan CCND1 (cyclin D1) merupakan gen yang meregulasi transisi G1/S pada siklus sel. Karsinoma sel skuamosa pada esophagus dengan amplifikasi kromosom 11q13 mengindikasikan amplifikasi gen CCNDI secara simultan. Duplikasi lengan panjang kromosom 11 menunjukkan adanya duplikasi beberapa tumor promoting gene yang berlokasi pada kromosom 11. Duplikasi daerah pada lengan panjang kromosom 11 mungkin merupakan tahap awal proses transformasi (Bajpai et al., 2012).

Gangguan siklus sel G1-S-G2-M menyebabkan terjadinya replikasi genom tanpa disertai pembelahan sel. Endoreplikasi sering tampak pada sel kanker dan dianggap sebagai precursor aneuploidy yang menyebabkan onkogenesis. Poliploidi (populasi 4n) dianggap berhubungan dengan keadaan pre-maligna epitelium yaitu sebagai penanda prediksi progresifitas. Instabilitas genom meningkat dengan bertambahnya usia pada mamalia. Populasi $4 \mathrm{n}$ pada sel BAR-T menunjukkan ciri khas fenomena penuaan. Belum diketahui apakah perkembangan poliploidi memang biasa terjadi pada sel imortal hTERT setelah kultur jangka lama (1 tahun) dan dapat memberikan keuntungan sebagai pertahanan hidup bagi sel. Tetapi pada kelompok kontrol tidak didapatkan tumorigenic karena sedikitnya jumlah gangguan pada gen spesifik kanker atau tekanan seleksi (Galipeau et al., 1996).

Penelitian ini memperkuat fakta yang ada di klinik bahwa perubahan karyotipe bisa dideteksi sebelum adanya displasia pada BE. Beberapa abnormalitas genetik, seperti mutasi gen, delesi gen, kehilangan heterozigositas, penyimpangan metilasi, penyimpangan ekspresi gen, dan penyimpangan kromosom dianggap sebagai marker untuk diagnosis progresifitas BE (Bajpai et al., 2012).

\section{Kesimpulan}

Paparan asam dan empedu jangka lama menginduksi gangguan kromosom dan seleksi klonal pada sel Barrett's epithelial (BAR-T) dan menyebabkan perkembangan neoplasia pada model BEC. Perubahan kromosom pada BEC mengawali perubahan morfologi berupa displasia. Gangguan kromosom bisa dijadikan penanda awal progresifitas Barrett's Esophagus. Kebanyakan gangguan kromosom yang 
diidentifikasi berhubungan dengan kanker lain dan berkaitan dengan progresifitas neoplastik pada model BEC. Perlu dilakukan validasi lebih lanjut secara in-vivo agar berguna secara klinik untuk diagnosis BE dan progresifitas menjadi Adenocarcinoma Esophagus.

\section{Daftar Pustaka}

Bajpai M., Aviv H., Das K.M., 2012. Prolonged Exposure to Acid and Bile Induces Chromosome Abnormalities That Precede Malignant Transformation of Benign Barrett's Epithelium. Molecular Cytogenetics Journal 2012, 5:43. Diakses 20 April 2013

Barrett, M.T., Sanchez C.A., Prevo L.J., Wong D.J., Galipeau P.C., Paulson T.G., Rabinovitch P.S., Reid B.J. 1999. Evolution of Neoplastic Cell Lineages in Barrett Oesophagus.http://www.researchgate .net/publication/12978533_Evolution _of_neoplastic_cell_lineages_in_Bar rett_oesophagus. Diakses 10 Mei 2013

Das, K.M., Kong Y., Bajpai M., Kulkarni D., Geng X., Mishra P., Banerjee D., Hirshfield K. 2011. Transformation of Benign Barrett's Epithelium by Repeated Acid and Bile Exposure Over 65 Weeks: a Novel In Vitro Model. Int $J$ Cancer. 2011 Jan 15;128(2):274-82. Diakses 12 Mei 2013

Garewall, H., Meltzer, P., Trent, J., Prabhala, R., Sampliner, R., Korc, M. Epidermal Growth Factor Receptor Overexpression and Trisomy in a Case of Barrett's Esophagus. Digestive Disease and Science, Vol. 35 No. 9

Gonzales, M,V., Artimez M,L., Rodrigo L., Lopez-Larrea C., Menendez M,J., Alvarez V., Perez R., Fresno M,F., Perez M,J., Sampedro A., Coto E. 1997. Mutation Analysis of the p53, APC, and p 16 Genes in the Barrett's Oesophagus, Dysplasia, and Adenocarcinoma. J Clin Pathol 1997;50:212-217

Hvid-Jensen, F., Pedersen, L., Drewes, AM., Sorensen, HT., Funch-Jensen, P. 2011. Incidence of Adenocarcinoma
Among Patients with Barrett's Esophagus. NEJM. Diakses 12 Mei 2013

Galipeau, PC., Cowan, DS., Sanchez, CA., Barret, MT., Emond, MJ. 1996. 17p (p53) Allelic Losses, $4 N$ (G2/tetraploid) Populations, and Progression to Aneuploidy in Barrett's Esophagus. Proc. Natl. Acad. Sci. USA Vol. 93, pp. 70817084, July 1996.

Limoli, C.L., Giedzinski, E., Morgan, WF., Swarts, SG., Jones, GDD., Hyun, W. 2003. Persistent Oxydative Stress in Chromosomally Unstable Cells. aacrjournal.org. Diakses 14 Mei 2013

Lobo, I. 2008. Chromosome Abnormalities and Cancer Cytogenetics. Nature Education

http://www.nature.com/scitable/topic page/Chromosome-Abnormalitiesand-Cancer-Cytogenetics-879

Masters, JR., Thomson, JA., Daly-Burnsa, B., Reid, YA., Dirks, WG., Packer, P., Toji, LH., Ohno, T., Tanabe, H., Arlett, CF., Kelland, LR., Harrison, M., $\quad$ Virmani, A., Wardn, TH., $\quad$ Ayreso, KL., Debenham, PG. 2001. Short Tandem Repeat Profiling Provides an International Refrence Standard for Human Cell Lines. http://www.pnas.org/content/98/14/8 012.long. Diakses 12 Mei 2013

Modiano, N; Gerson, LB. 2007. Barrett's Esophagus: Incidence, Etiology, Pathophysiology, Prevention and Treatment. NCBI Journal. Diakses 12 Mei 2013

McPhee, S.J., Papadakis, M.A., 2007. Current Medical Diagnosis and Treatment, Forty-sixth Edition. United States of America: McGraw Hill Companies

Ndraha, S. 2014. Penyakit Refluks Esofageal. Medicinus Vol. 27, No. 1 April 2014

NIDDK. 2008. Barrett's Esohagus. US Department of Health and Human Service. http://digestive.niddk.nih.gov/ddiseas es/pubs/barretts/

NeoGenomic Laboratory. 2013. NeoSITE ${ }^{\mathrm{TM}}$ B.E.

Barrett's Esophagus FISH Panel: A 
Diagnostic Tool for Assessment of Genetic Abnormalities As Indicators of Malignancy. http://www.neogenomics.com/neosit e-barretts-esophagus-fish-panel.htm

Oryu, M., Mori, H., Kobara, H., Nishiyama, N., Fujihara, S., Kobayashi, M., Yasuda, M., Masaki, T. 2013. Review Article: Differences in the Characteristics of Barrett's Esophagus and Barrett's Adenocarcinoma between the United Stateds and Japan. ISRN Gastroenterology

Pluymers M., Marian B. E., Van Drunen, Ellen; Vissers, Kees J.; Mulder, Andries H.; Tilanus, Hugo W.; Hagemeijer,

Anna. 1996. Cytogenetic Analysis of Barretts Mucosa and Adenocarcinoma of the Distal Esophagus and Cardia. Cancer Genetics \& Cytogenetics. 90(2): 109117

Renoat, H. 2013. Asuhan Keperawatan GERD. Fakultas Ilmu Keperawatan Universitas Indonesia Timur Makassar

Schneider, B., L. and Martin M., K. 2004. Destructive cycles: the Role of Genomic Instability and Adaptation in Carcinogenesis. Carcinogenesis Vol. 25 No.11. Oxford University Press

Shields HM, Nardone G, Zhao J, Wang W, Xing $Z$, Fang D, Jacobson BC, Romero Y, Dvorak K, Goldman A, Pellegrini CA, Wiley EL, Peura DA, Tatum RP, Schnell TG. 2011. Barrett's Esophagus: Prevalence and Incidence of Adenocarcinomas. Annals of the New York Academy of Science.Issue:Barrett's Esophagus: The $10^{\text {th }}$ OESO World Congress Preceedings

UF Pathlab. 2009. ISCN (2005) Nomenclature Discontinued.

http://pathlabs.ufl.edu/news/cytogene tics-news-iscn-discontinued. Diakses 15 mei 2013

Walch, AK., Zitzelsberger, HF., Bruch, J., Keller, G., Angermeier, D., Aubele, MM., Mueller, J., Stein, H., Braselmann, H., Siewert, JR., Höfler, H., Werner, M. 2000. Chromosomal
Imbalances in Barrett's

Adenocarcinoma and the Metaplasia-Dysplasia-Carcinoma

Sequence. Am J Pathol. 